\title{
Antifungal activity of soybean rhizosphere actinomycetes producing bioactive compounds against Fusarium oxysporum
}

\author{
HIMA DEWI MARIASTUTI ${ }^{1}$, SRI LISTIYOWATI ${ }^{1}$, ARIS TRI WAHYUDI ${ }^{1, \boldsymbol{}}$ \\ ${ }^{1}$ Department of Biology, Faculty of Mathematics and Natural Sciences, Institut Pertanian Bogor. Jl. Raya Dramaga, Bogor 16680, West Java, Indonesia. \\ Tel./fax.: +62-251-8622833, ’email: aristri2011@gmail.com
}

Manuscript received: 13 October 2018. Revision accepted: 27 October 2018.

\begin{abstract}
Mariastuti HD, Listiyowati S, Wahyudi AT. 2018. Antifungal activity of soybean rhizosphere actinomycetes producing bioactive compounds against Fusarium oxysporum. Biodiversitas 19: 2127-2133. Actinomycetes are known as the most potential source bioactive compounds. This research aimed to explore the potential of actinomycetes isolated from rhizosphere of soybean in antifungal activity against Fusarium oxysporum, a pathogen causing damping off, wilt, and root rot in soybean. Of 18 actinomycetes isolates tested, 9 isolates had antifungal activity against $F$. oxysporum in different inhibition percentages ranging from $38.69 \%$ to $73.50 \%$. The lowest and the highest inhibition percentage were performed by ARK 63 and ARK 94 respectively. As tested by compatibility assay, all of isolates were compatible toward Bradyrhizobium japonicum, a symbiotic bacteria which colonized the soybean root confirmed by no clear zone formed in the agar medium. The activity of 9 isolates was confirmed in sterile and nonsterile soil toward in planta test. All of these isolates exhibited the consistent antifungal activity both in vitro and in planta. The diseases suppression in sterile soil was ranging from $36 \%$ to $80.7 \%$ while in non-sterile soil was ranging from $67 \%$ to $100 \%$. The highest disease suppression in sterile soil was performed by ARK 17 while in non-sterile soil was performed by ARK 92 and ARK 94. Supporting the results, 5 crude extracts of the potential isolates also showed the antifungal activity with inhibition percentage ranging from $19 \%$ to $54.09 \%$. The highest inhibition percentage was performed by ARK 94. ARK 94 showed consistent inhibition against $F$. oxysporum in vitro, in planta, and also in crude extract assay. Chemical composition of crude extract derived from ARK 94 was identified by gas chromatography-mass spectrometry (GC-MS) analysis. Among 12 major compounds, 7 compounds act as antifungal based on some references. Based on those potential characters, this isolate is potential to be further developed as biocontrol agent.
\end{abstract}

Keywords: Antifungal activity, bioactive compounds, GC-MS, rhizosphere actinomycetes

\section{INTRODUCTION}

Soilborne fungal pathogen is one of serious crop problems in Indonesia, particularly fungi infecting soybean. Some phytopathogens including Aspergillus niger, A. flavus, Fusarium spp., Penicillium sp., Cladosporium sp., Sclerotium rolfsii, Rhizoctonia solani, Pythium sp., Phytophthora sp., and Rhizopus sp. were reported to be the most common factor decreasing soybean productivity (Semangun 2008). One of these pathogens, $F$. oxysporum can survive in the soil, both as mycelium and as spores in the absence of its hosts (Agrios 2005). This fungus caused stunting in growth, necrosis, and chlorosis of cotyledon, root rot, vascular wilt, and damping-off of in soybean plant (Mbofung et al. 2007). Previous studies reported that $F$. oxysporum also caused wilt disease in chickpea (Gopalakrishnan et al. 2011), Chinese cabbage (Khamna et al. 2009), and cucumber wilt (Yang et al. 2011). Therefore, this pathogen should be suppressed to improve soybean productivity.

Presently, the use of chemical fungicide at a high concentration may increase the resistance of the pathogen and impact on non-target species. In short, the chemical fungicide in a long-term would result in another ecological problem (Haas et al. 2000). The application of biological agent as biocontrol is widely developed against pathogen in soybean. The effects tend to be environmentally friendly and low-cost. Biological control agent can potentially be isolated from suppressive soil due to the existence of antagonistic microorganisms as a natural competitor in the habitat, especially actinomycetes (Mazzolla 2002). Actinomycetes are also recognized for their ability to colonize plants (Barakate et al. 2002). Actinomycetes which colonized rhizosphere were able to improve plant growth both by direct (by producing some phytohormones and increasing soil nutrient availability) and indirect mechanisms (by producing bioactive compounds against pathogen).

Actinomycetes are known as a producer of potential microbial bioactive compounds. From 500 bioactive compounds identified, $45 \%$ were produced by actinomycetes, $38 \%$ by fungi, and $17 \%$ by unicellular bacteria as reported by Demain and Sanchez (2009). These compounds have some biological antifungal activities against $F$. oxysporum (Khamna et al. 2009), Fusarium causing wilt in sorghum (Kavitha et al. 2010), F. oxysporum f. sp. cubense race 4 (Zacky and Ting 2013 ), and $F$. graminearum causing head blight in the grain of wheat and barley (Ito et al. 2012). In the previous study, 18 actinomycetes isolates have successfully been isolated from Sukabumi, West Java, Indonesia (Kurniati 2017). These isolates attributed to 
plant growth promotion (PGP) character, including IAA production, phosphate solubilization, nitrogen fixation, and promotion soybean growth in vitro. The antifungal activity against phytopathogen particularly $F$. oxysporum has not been reported yet. Hence, in the present study, 18 isolates of actinomycetes were screened for actinomycetes that contain antagonistic potential against $F$. oxysporum. The objective of this study was to evaluate the capability of potential actinomycetes isolated from soybean rhizosphere in inhibiting the growth of $F$. oxysporum in vitro and in planta.

\section{MATERIALS AND METHODS}

\section{Isolates preparation}

A total of 18 actinomycetes isolates used in this study have been isolated in the previous study (Kurniati 2017). These isolates were routinely cultured on yeast malt agar (ISP2) medium (yeast extract $4 \mathrm{~g} / \mathrm{L}$, malt extract $10 \mathrm{~g} / \mathrm{L}$, glucose $4 \mathrm{~g} / \mathrm{L}$, agar $20 \mathrm{~g} / \mathrm{L}$ ). Fusarium oxysporum was obtained from Department of Plant Protection, Bogor Agricultural University, Indonesia. This fungal was recultured on potato dextrose agar (PDA) medium for 7 days.

\section{Screening of antifungal activity from actinomycetes against $\boldsymbol{F}$. oxysporum}

The screening was conducted in PDA medium by dual culture method (Khare et al. 2010). The actinomycetes were streaked $3 \mathrm{~cm}$ from the center of petri dish. After 48 hours, $F$. oxysporum was inoculated in the center of petri dish $(6 \mathrm{~mm}$ in diameter). The culture was then incubated for 7 days at $28^{\circ} \mathrm{C}$. The antifungal activity was determined by calculating the radial growth of hypha. This assay was examined in 5 replicates. The inhibition percentage was calculated by using the following formula :

\section{Inhibition percentage $=(D 1-D 2) / D 1 \times 100 \%$}

Where:

D1: the diameter of radial hypha in the edge of petri $\operatorname{dish}(\mathrm{cm})$

D2: the diameter of radial hypha close to actinomycetes colony $(\mathrm{cm})$

\section{Compatibility assay}

The compatibility of actinomycetes isolates with Bradyrhizobium japonicum was evaluated. This assay was tested based on previous research conducted by Huddleston et al. (1997). Melted yeast mannitol agar (YMA) medium (yeast extract $0.5 \mathrm{~g} / \mathrm{L}$, mannitol $10 \mathrm{~g} / \mathrm{L}, \mathrm{K}_{2} \mathrm{HPO}_{4} 0.5 \mathrm{~g} / \mathrm{L}$, $\mathrm{MgSO}_{4} .7 \mathrm{H}_{2} \mathrm{O} 0.2 \mathrm{~g} / \mathrm{L}, \mathrm{NaCl} 0.1 \mathrm{~g} / \mathrm{L}$, agar $20 \mathrm{~g} / \mathrm{L}$ ) was inoculated with $8 \%$ of 4-day-old $B$. japonicum then poured into petri dish as basal layer. After the inoculated medium was solid, a paper disk (6 $\mathrm{mm}$ in diameter) was placed onto the medium. Nearly $10 \mu \mathrm{L}$ of each actinomycetes culture was dropped on the paper disk and incubated for 7 days. The antagonistic interaction was indicated by the formation of clear zone around the paper disk.

\section{In planta test}

The nine actinomycetes with antifungal property against $F$. oxysporum in dual culture method were then evaluated for their antifungal activity in the greenhouse. The actinomycetes isolates were cultured on ISP4 agar medium. The preparation consisted of 3 steps. The first step was a soil preparation. The soil was composed of ultisol soil, compost, and sand with a ratio of $2: 1: 1$. The soil served as sterile and non-sterile soil. The sterile soil was autoclaved for 1 hour within 2 consecutive days at 121 ${ }^{\circ} \mathrm{C}$ (Susilowati et al. 2011). The second step was preparing the spores of $F$. oxysporum. $F$. oxysporum was cultured on potato dextrose broth (PDB) medium supplemented with rifampicin $(50 \mu \mathrm{g} / \mathrm{mL})$. The culture was incubated for 7 days. A total spore of $10^{3} \mathrm{CFU} / \mathrm{mL}$ was used for in planta test and inoculated in the soils. The third step was preparation of actinomycetes and the seed. The method of seed coating based on previous research conducted by Jogaiah et al. (2016). The isolates of actinomycetes on ISP4 agar medium were scrapped to obtain the spores, which were then collected in a $1.5 \mathrm{ml}$ tube. The spores were washed twice using $\mathrm{NaCl} 0.85 \%$ then centrifuged to separate the cells. Pellet was mixed with carboxyl methyl cellulose (CMC) $0.8 \%$ as a carrying medium. The soybean seeds were sterilized in $\mathrm{NaClO} 1.5 \%$ and washed twice using sterile distilled water. After sterilization, soybean seeds were soaked in CMC medium for 3 hours in an incubator shaker. Control seeds were soaked in the CMC medium without actinomycetes spores. This assay was served in 3 replicates. Each replicate consisted of 5 plants. At 7 days after planting, the disease suppression was calculated using the formula of Wiyono (2003):

\section{Disease suppression $=\left(X-C^{+}\right) /\left(C^{-}-C^{+}\right) \times 100 \%$}

Where:

$\mathrm{X}$ : number of uninfected plants in treatments with actinomycetes and $F$. oxysporum

$\mathrm{C}^{-}$: number of uninfected plants in treatment without actinomycetes and $F$. oxysporum

$\mathrm{C}^{+}$: number of uninfected plants in treatment with $F$. oxysporum, but not treated with actinomycetes

\section{Antifungal activity of crude extract assay}

Five potential isolates of actinomycetes toward $F$. oxysporum (as screened in in planta test) were cultured on ISP2 broth medium at $28{ }^{\circ} \mathrm{C}$ for 10 days in the incubator shaker. The centrifugation was conducted to separate supernatant from the cells. The centrifugation was performed at $4000 \mathrm{rpm}$ and $4{ }^{\circ} \mathrm{C}$ for 15 minutes. Ethyl acetate then was added to the supernatant $(\mathrm{v} / \mathrm{v} ; 1: 1)$. It was then shaken continuously for 30 minutes. The solvent was evaporated at $50{ }^{\circ} \mathrm{C}$ to obtain the crude extract. To evaluate the extract in the activity against $F$. oxysporum, the extract was diluted in dimethyl sulfoxide (DMSO) until $5000 \mathrm{ppm}$ in concentration. Each extract was mixed with melted PDA medium and poured into petri dish. After medium was solid, hypha of $F$. oxysporum was placed on it. Control treatment was served by inoculating $F$. oxysporum on the PDA medium contained DMSO only (v/v; 20:1). The 
treatment was served in 3 replicates. The incubation was done for 7 days at room temperature. The inhibition percentage was measured by comparing the diameter of hyphal growth in the treatment and control.

\section{Gas chromatography-mass spectrometry (GC-MS) analysis}

The most potential crude extract (ARK 94) in inhibiting growth of $F$. oxysporum was identified by using GC-MS analysis. The column used in HP-5MS (5\% phenyl methyl siloxane) capillary column of dimension $30.0 \mathrm{~m} \times 250 \mu \mathrm{m} \times$ $0.25 \mu \mathrm{m}$ and used helium as carrier gas at $1 \mathrm{~mL} / \mathrm{min}$. The column temperature was initially at $40{ }^{\circ} \mathrm{C}$ for 10 minutes then followed by an increase of $3{ }^{\circ} \mathrm{C} / \mathrm{min}$ to $250{ }^{\circ} \mathrm{C}$. The temperature then was set isothermally for 5 minutes. The MS was operating at $70 \mathrm{eV}$. The compounds then were identified by comparison of their mass spectral data with those from NIST 05 Spectral Library.

\section{RESULTS AND DISCUSSION}

\section{Antifungal activity of actinomycetes in dual culture method against $F$. oxysporum}

Nine out of eighteen isolates of actinomycetes were potential in inhibiting $F$. oxysporum. Hypha of $F$. oxysporum was inhibited by actinomycetes colony as shown by reducing growth of hypha which faced actinomycetes colony (Figure 1). The highest inhibition percentage was performed by ARK $94(73.50 \%)$ and the lowest one was performed by ARK 63 (38.69\%) as shown in (Table 1). However, $50 \%$ of isolates showed antifungal activity against $F$. oxysporum.

\section{Response of compatibility assays}

The potential isolates of actinomycetes against $F$. oxysporum showed compatibility toward Bradyrhizobium japonicum. Based on this assay, all of the 9 isolates are compatible with $B$. japonicum as indicated by no clear zone formed (data not shown).

\section{Antifungal activity of actinomycetes isolates in the greenhouse}

All data showed disease suppression in both sterile and non-sterile soils (Table 2). Consistently, the actinomycetes isolates which have antifungal activity in vitro also performed antifungal activity in the greenhouse. The highest disease suppression was performed by ARK 17 $(83 \%)$ in sterile soil and ARK $94(100 \%)$ and ARK 92 $(100 \%)$ in non-sterile soil. The disease suppression was relatively higher in non-sterile soil than that in sterile soil. The lowest disease suppression was shown by the same isolate in both soils, ARK 103.

\section{Antifungal activity of crude extract from actinomycetes isolates}

Five potential actinomycetes confirmed by in planta test (ARK 13, ARK 17, ARK 68, ARK 92, and ARK 94) were analyzed their crude extracts activity toward $F$. oxysporum. The growth of $F$. oxysporum's hypha was inhibited by all of the 5 crude extracts in $5000 \mathrm{ppm}$ concentration (Figure 2). The highest inhibition percentage was shown by ARK 94, which was $54.09 \%$. $F$. oxysporum's hypa was smaller compared with control treatment (DMSO only) (Figure 1).

Table 1. Antifungal activity of actinomycetes isolates against $F$. oxysporum

\begin{tabular}{cccc}
\hline Isolate & $\begin{array}{c}\text { Inhibition } \\
\text { percentage }\end{array}$ & Isolate & $\begin{array}{c}\text { Inhibition } \\
\text { percentage }\end{array}$ \\
\hline ARK 13 & $51.25 \pm 6.5$ & ARK 63 & $38.69 \pm 9.7$ \\
ARK 16 & $45.48 \pm 1.5$ & ARK 68 & $70.43 \pm 4.9$ \\
ARK 17 & $38.81 \pm 5.4$ & ARK 86 & - \\
ARK 26 & - & ARK 87 & - \\
ARK 28 & - & ARK 92 & $62.09 \pm 3.4$ \\
ARK 47 & - & ARK 94 & $73.50 \pm 6.5$ \\
ARK 48 & - & ARK 103 & $53.64 \pm 8.8$ \\
ARK 49 & - & ARK 108 & - \\
ARK 51 & $44.55 \pm 5.3$ & ARK 116 & - \\
\hline
\end{tabular}

Note:- : no antifungal activity

Table 2. Antifungal activity of 9 actinomycetes isolates against $F$. oxysporum in the greenhouse

\begin{tabular}{|c|c|c|c|c|c|c|}
\hline \multirow[b]{2}{*}{ Treatment } & \multicolumn{3}{|c|}{ Sterile soil* } & \multicolumn{3}{|c|}{ Non sterile soil* } \\
\hline & $\begin{array}{c}\text { Infected } \\
\text { plant }\end{array}$ & $\begin{array}{c}\text { Uninfected } \\
\text { plant }\end{array}$ & $\begin{array}{c}\text { Disease } \\
\text { suppression }\end{array}$ & $\begin{array}{c}\text { Infected } \\
\text { plant }\end{array}$ & $\begin{array}{c}\text { Uninfected } \\
\text { plant }\end{array}$ & $\begin{array}{c}\text { Disease } \\
\text { suppression }\end{array}$ \\
\hline F. oxysporum & 73 & 27 & - & 60 & 40 & - \\
\hline Control (without $F$. oxysporum and actinomycetes) & 0 & 100 & - & 0 & 100 & - \\
\hline F. oxysporum + ARK 13 & 20 & 80 & $72.3 \pm 0.05$ & 13 & 87 & $78 \pm 0.19$ \\
\hline F. oxysporum +ARK 16 & 27 & 73 & $64.0 \pm 0.13$ & 20 & 80 & $78 \pm 0.19$ \\
\hline F. oxysporum +ARK 17 & 13 & 87 & $83.3 \pm 0.29$ & 7 & 93 & $89 \pm 0.19$ \\
\hline F. oxysporum +ARK 51 & 40 & 60 & $44.3 \pm 0.98$ & 20 & 80 & $67 \pm 0.34$ \\
\hline F. oxysporum + ARK 63 & 20 & 80 & $72.3 \pm 0.25$ & 20 & 80 & $67 \pm 0.00$ \\
\hline F. oxysporum + ARK 68 & 20 & 80 & $75.0 \pm 0.25$ & 7 & 93 & $89 \pm 0.19$ \\
\hline F. oxysporum + ARK 92 & 13 & 87 & $80.7 \pm 0.17$ & 0 & 100 & $100 \pm 0.0$ \\
\hline F. oxysporum + ARK 94 & 20 & 80 & $75.0 \pm 0.25$ & 0 & 100 & $100 \pm 0.0$ \\
\hline F. oxysporum + ARK 103 & 47 & 53 & $36.0 \pm 0.13$ & 20 & 80 & $67 \pm 0.00$ \\
\hline
\end{tabular}

Note: *: The data was an average of 3 replicates in percentage 
Table 3. Chemical composition in the crude extract derived from an actinomycete ARK 94

\begin{tabular}{|c|c|c|c|c|c|}
\hline Chemical composition & $\begin{array}{l}\text { Molecular } \\
\text { structure }\end{array}$ & $\begin{array}{l}\text { Retention } \\
\text { time }\end{array}$ & $\begin{array}{c}\text { Peak } \\
\text { area }(\%)\end{array}$ & $\begin{array}{l}\text { Similarity } \\
(\%)\end{array}$ & Bioactivity (References) \\
\hline Benzene, ethenyl- & $\mathrm{C}_{16} \mathrm{H}_{16}$ & 2.64 & 10.94 & 96 & $\begin{array}{l}\text { antibacterial, antifungal } \\
\text { (Al-Marzoqi et al. 2016) }\end{array}$ \\
\hline 2.4- Diphenyl- 1- butene & $\mathrm{C}_{16} \mathrm{H}_{16}$ & 9.60 & 3.48 & 64 & $\begin{array}{l}\text { antibacterial, antifungal } \\
\text { (Arbi et al. 2011) }\end{array}$ \\
\hline $\begin{array}{l}\text { Benzene, 1.1'-(1.2-cyclobutanediyl)bis-, trans- } \\
\text { (CAS) }\end{array}$ & $\mathrm{C}_{16} \mathrm{H}_{16}$ & 9.86 & 5.04 & 90 & $\begin{array}{l}\text { antibacterial } \\
\text { (Ravichandiran et al. 2013) }\end{array}$ \\
\hline Benzonitrile, m-phenethyl- & $\mathrm{C}_{18} \mathrm{H}_{21} \mathrm{~N}$ & 14.25 & 17.59 & 27 & $\begin{array}{l}\text { antibacterial } \\
\text { (Dahpour et al. 2012) }\end{array}$ \\
\hline 1-(2-Methylprop-1-en-1-yl)-9H-pyrido[3.4-b]indole & $\mathrm{C}_{15} \mathrm{H}_{14} \mathrm{~N}_{2}$ & 14.88 & 14.08 & 83 & $\begin{array}{l}\text { anticancer (Khan et al. 2014) } \\
\text { antimalarial ( Kuo et al. 2004) }\end{array}$ \\
\hline 4-(Methylphenyl)indole & $\mathrm{C}_{15} \mathrm{H}_{13} \mathrm{~N}$ & 14.97 & 21.46 & 83 & $\begin{array}{l}\text { antibacterial, antiviral, } \\
\text { anticancer (Rao et al. 2011) }\end{array}$ \\
\hline 1.1-dicyano-2-methyl-3-(p-cyanophenyl)propene & $\mathrm{C}_{13} \mathrm{H}_{9} \mathrm{~N}_{3}$ & 15.02 & 6.84 & 83 & $\begin{array}{l}\text { antifungal, insecticidal } \\
\text { (Kang et al. 2012; Lim et al. 2008) }\end{array}$ \\
\hline 1H-Indole, 2-methyl-3-phenyl- & $\mathrm{C}_{15} \mathrm{H}_{13} \mathrm{~N}$ & 15.07 & 8.53 & 78 & $\begin{array}{l}\text { antifungal, antibacterial, antioxidant } \\
\text { (Oloyede et al. 2011) }\end{array}$ \\
\hline $\begin{array}{l}\text { 2.5-Cyclohexadiene-1.4-dione, } 2.3 \text { - dimethoxy-5-(1- } \\
\text { methyl-2-propenyl)-6-(phenylmethyl)- }\end{array}$ & $\mathrm{C}_{19} \mathrm{H}_{20} \mathrm{O}_{4}$ & 15.68 & 3.78 & 27 & $\begin{array}{l}\text { antifungal, antibacterial, } \\
\text { anticancer } \\
\text { (Mohamed et al. 2015) }\end{array}$ \\
\hline $\begin{array}{l}\text { Nickel, [(1.2.5.6-.eta.)-1.5-cyclo } \\
\text { octadiene]bis(trimethylphosphine)- }\end{array}$ & $\mathrm{C}_{14} \mathrm{H}_{30} \mathrm{NP}_{2}$ & 17.83 & 3.78 & 89 & unknown \\
\hline $\begin{array}{l}\text { 2.3 Diphenyl cyclopropyl) methyl Phenyl } \\
\text { Sulfoxide,trans- }\end{array}$ & $\mathrm{C}_{22} \mathrm{H}_{20} \mathrm{OS}$ & 15.85 & 1.34 & 16 & $\begin{array}{l}\text { antibacterial, antifungal } \\
\text { (Bayrak et al. 2009) }\end{array}$ \\
\hline $\begin{array}{l}\text { Benzaldehyde, 4-[1-[4-(acetyloxy)-3.5- } \\
\text { dimethoxyphenyl]ethoxy]-3-methoxy- }\end{array}$ & $\mathrm{C}_{20} \mathrm{H}_{22} \mathrm{O}_{7}$ & 17.27 & 1.71 & 25 & $\begin{array}{l}\text { antibacterial, antifungal } \\
\text { (Oloyede et al. 2011) }\end{array}$ \\
\hline
\end{tabular}
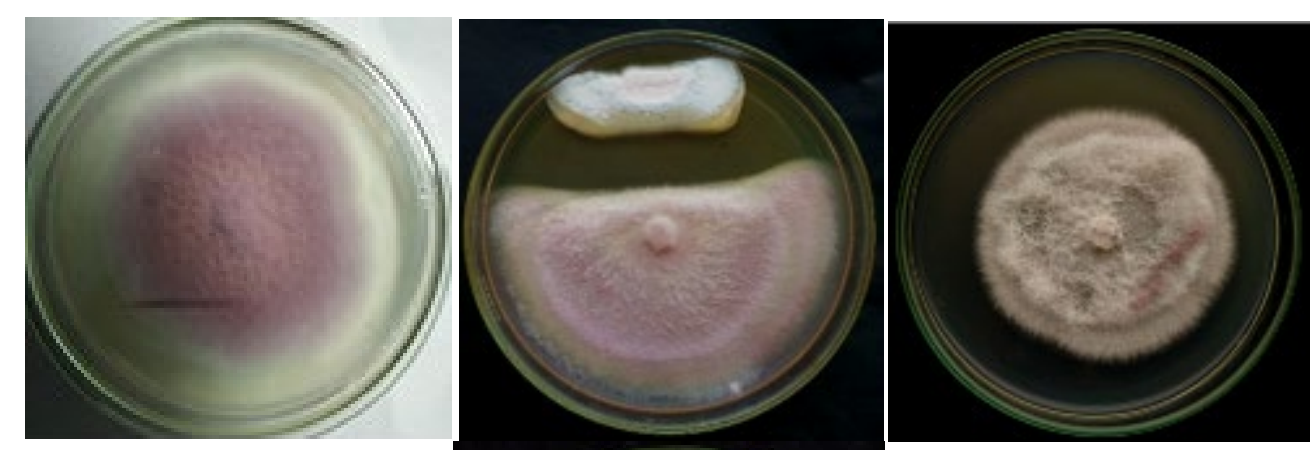

A

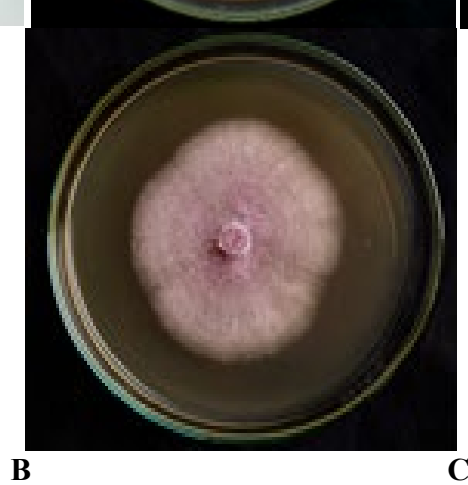

D

Figure 1. Colony of F. oxysporum, (A) control, (B) antifungal activity of ARK 94, (C) on medium contained DMSO, (D) on medium contained ARK 94 crude extract in $5000 \mathrm{ppm}$, after incubated on PDA at $\pm 28^{\circ} \mathrm{C}$ for 7 days 


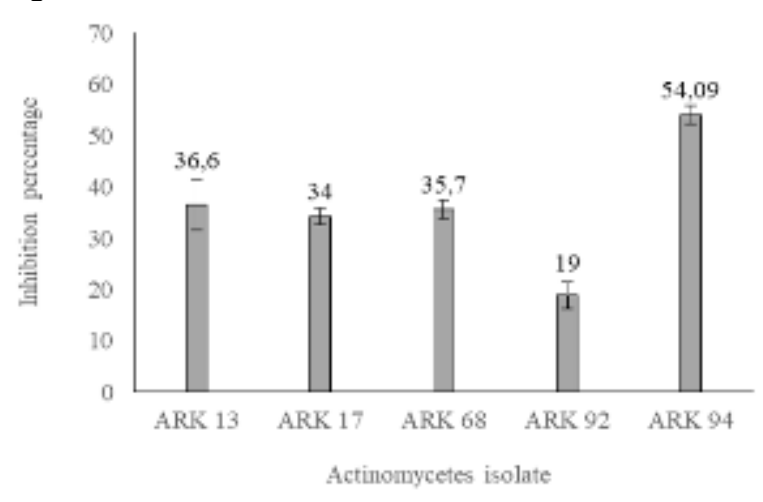

Figure 2. Inhibition percentage of crude extract from 5 actinomycetes isolates against $F$. oxysporum

\section{Chemical compound of actinomycetes isolate ARK 94}

The composition of chemical compounds in the ARK 94 was analyzed by GC-MS. The chemical compounds were detected in the various retention time, peak area, and similarity (Table 3). There were 12 major compounds in the crude extract which had bioactivity based on some references. Two compounds had high similarity including Benzene, 1.1'-(1.2-cyclobutanediyl) bis-, trans- (CAS) and Benzene, ethenyl with $90 \%$ and $96 \%$ similarity respectively.

\section{Discussion}

Soybean rhizosphere is a potential source of promising actinomycetes in the protection of soybean plant against $F$. oxysporum causing wilt root. Nine isolates (50\%) out of 18 actinomycetes isolates, showed antifungal activity against $F$. oxysporum in dual culture method (in vitro). The differences of their antifungal activity indicate the chemical diversity of antifungal compound produced by these actinomycetes. Among 9 potential isolates in dual culture method, 5 isolates exhibited inhibition against $F$. oxysporum by up to 50\% (ARK 13, ARK 68, ARK 92, ARK 94, and ARK 103). Surprisingly, ARK 94 was able to inhibit growth of $F$. oxysporum until $73.50 \%$. These potential isolates likely produced antifungal compounds so that the radial hypha's growth was inhibited. Production of antibiotic, secretion of lytic enzymes in degrading fungal cell wall, mycoparasitism, and competition for space and nutrients were some possible mechanisms in biocontrol reactions toward pathogen (Vinale et al. 2008). The inhibition zone by actinomycetes isolates in our study might suggest some diffusible inhibitory substances in the medium that affected the growth of $F$. oxysporum's hypha.

The activities of the 9 potential actinomycetes in dual culture method were confirmed in the greenhouse by in planta test in sterile and non-sterile soil. These activities were shown by the number of uninfected plants which was higher in both soils compared to positive control (seeds was treated with $F$. oxysporum, but not treated with actinomycetes). The number of uninfected plant in sterile soil reached $53 \%$ to $87 \%$ meanwhile in non-sterile soil reached $80 \%$ to $100 \%$ (Table 2). Consistently, 9 isolates showed antifungal activity both in vitro and in planta, suggesting that their antifungal activity was stable in both conditions. Getha and Vikineswary (2002) reported that the ability of actinomycetes in vitro will also have the same effect in the in planta test. The antifungal activity was shown by all isolates in protecting soybean confirmed that microorganism isolated from a specific plant root or rhizosphere provided better disease suppression when applied in the same habitat. As previously reported by Zhang et al. (2009), microorganism isolated from soil of soybean had better protection from another microorganism isolated from soil of corn against Fusarium root rots of soybean.

Although the activity was stable against $F$. oxysporum both in vitro and in planta, some isolates such as ARK 103 and ARK 17 showed different potential of antifungal activity during in planta and in vitro test. The antifungal activity of ARK 103 in the in vitro test was reached $53.64 \%$ inhibition compared to ARK 17 which only reached $38.81 \%$ inhibition while the antifungal activity of ARK 103 was poor during in planta test in both sterile and non-sterile soils compared to ARK 17. ARK 17 performed high disease suppression in both soils which reached up to $80 \%(83.3 \%$ in sterile soil and $89 \%$ in non-sterile soil) while ARK 103 only performed $36 \%$ disease suppression in sterile soil and $67 \%$ in non-sterile soil. This different activity indicated some factors that influenced the production of bioactive compounds. One factor might be due to different medium content in both conditions. Another factor might be due to differential survival and colonization of actinomycetes isolates on soybean root. The colonization on target sites was important in promoting good protection by biological agent. The colonization enhanced the contact between biological agent and pathogen (Zhang et al. 2009). Considering the ability of survival and the protection, ARK 17 was claimed more stable and having high protection than ARK 103.

Most of actinomycetes isolates exhibited higher disease suppression in non-sterile soil than in sterile soil. The isolates performed $36 \%$ to $80.7 \%$ disease suppression in sterile soil and $67 \%$ to $100 \%$ disease suppression in nonsterile soil. In addition, two actinomycetes isolated showed $100 \%$ disease suppression in non-sterile soil. They were ARK 92 and ARK 94. The variation of the suppression percentage which was higher in non-sterile than in sterile soil indicating that the antifungal activity was possibly affected by the growth condition, such as $\mathrm{pH}$ and content of nutrient. The disease suppression in sterile soil might be higher with some nutrients added like previous researches using sterile soil in the greenhouse as reported by Hamdali et al. (2008) and El-Tarabily et al. (2010). The soil was determined its composition such as the total carbon $(\mathrm{Ct})$, nitrogen $(\mathrm{Nt})$, soluble phosphorus content, and also soil $\mathrm{pH}$ before the greenhouse treatment. The result showed a high disease suppression in that soil against Phytium aphanidermatum (El-Tarabily et al. 2010) and Phytium ultimum (Hamdali et al. 2008).

García et al. (2010) stated that organic carbon will affect microbial activity. The increasing of the organic carbon in soil will improve the quantity and quality of microorganism. In this study, the nutrient content such as organic carbon might be different from sterile and non- 
sterile soil caused by sterilization process. The nutrient in sterile soil might be lower than in non-sterile soil and affect the antifungal compound pathway. Another aspect is the existence of soil microbiome. Non-sterile soil provides some beneficial indigenous microbes that may positively increase the growth of plant while in sterile soil, these beneficial microbes were killed or eliminated. Goudjal et al. (2014) also stated that indigenous microbes in nonsterile soil might interact with introduced actinomycetes to enhance the antifungal activity. In instance, the soil condition likely affects the effectiveness of disease suppression by actinomycetes.

Extracts of potential actinomycetes performed antifungal activity against the growth of $F$. oxysporum hypha in various inhibition percentages in ranging from $19 \%$ to $54.09 \%$. The antifungal activity of the isolates extracts indicating that the antifungal compounds were extracellularly secreted. The extract was diffusible into medium so that the $F$. oxysporum's growth was inhibited. Preceding study also reported the activity of Streptomyces plicatus in inhibiting $80-100 \%$ the growth of Phytophthora infestans and Sclerotium rolfsii at the concentration of 2000-5000 ppm (Sinha et al. 2014). Zacky and Ting (2013) also emphasized that the dilution of crude extract would affect the biological control against pathogenic fungi. Purification and elucidation of that extract are necessary to improve its antifungal activity.

Metabolites extracted from ARK 94 contained 12 types as dominant chemical compounds. Seven compounds were identified as Benzene, ethenyl-, 2.4- Diphenyl- 1- butene, 1.1-dicyano-2-methyl-3-(p-cyanophenyl) propene, $1 \mathrm{H}$ Indole, 2-methyl-3-phenyl-, 2.5-Cyclohexadiene-1.4-dione, 2.3- dimethoxy-5-(1-methyl-2-propenyl)-6-(phenylmethyl), 2.3 Diphenyl cyclopropyl) methyl Phenyl Sulfoxide,trans-, and Benzaldehyde, 4-[1-[4-(acetyloxy)-3.5dimethoxyphenyl] ethoxy]- 3-methoxy. These compounds act as antifungal as well as antibacterial, anticancer, antioxidant, and insecticidal (Table 3). There were 2 compounds with similarities $90 \%$ and $96 \%$, Benzene, 1.1'(1.2-cyclobutanediyl) bis-, trans- (CAS) and Benzene, ethenyl. Other compounds showed lower similarity (16\%), suggesting the novelty of the compounds. Therefore, further research is needed to identify this compound.

Based on the results of this study, actinomycetes has great potency as a biocontrol agent for soybean plant against $F$. oxysporum. A total of 9 from 18 isolates of actinomycetes showed antifungal activity against $F$. oxysporum both in vitro and in planta test. Consistently, ARK 94, the most potential isolate performed the highest antifungal activity in vitro, in planta, and crude extract assay. ARK 94 crude extract contained 12 major compounds which 7 compounds were confirmed as antifungal. Our results strongly indicate that the activity of antifungal is caused by these chemical compositions. This study provides further possibilities to analyze novel bioactive compound in various approaches.

\section{ACKNOWLEDGEMENTS}

This research was partly supported by the Ministry of Research, Technology, and Higher Education of Indonesia through "Penelitian Dasar Unggulan Perguruan Tinggi (PD-UPT)" to Prof. Aris Tri Wahyudi under contract no.1735/IT3.11/PN/2018, and partly supported by LPDP (Lembaga Penelitian Dana Pendidikan) from the Ministry of Finance, the Republic of Indonesia. Therefore, we appreciate and thank to all supports given to this research.

\section{REFERENCES}

Agrios GN. 2005. Plant Pathology. $5^{\text {th }}$ Edition. London, United Kingdom. Al-Marzoqi AH, Hadi MY, Hameed IH. 2016. Determination of metabolites products by Cassia angustifolia and evaluate antimicrobial activity. J Pharmacognosy Phytother 8: 25-48.

Arbi ME, Pigeon P, Top S, Rhouma A, Aifa S, Rebai A, Vassieres A, Plamont MA, Jaouen G. 2011. Evaluation of bactericidal and fungicidal activity of ferrocenyl or phenyl derivatives in the diphenyl butene series. J Organomet Chem 696:1038-1048.

Barakate M, Ouhdouch Y, Oufdou K, Beaulieu C. 2002. Characterization of rhizospheric soil Streptomyces from Moroccan habitats and their antimicrobial activities. World J Microbiol Biotechnol 18: 49-54.

Bayrak H, Demirbas A, Karaoglu SA, Demirbas N. 2009. Synthesis of some new 1,2,3-triazole, their Mannich and Schiff bases and evaluation of their antimicrobial activities. Eur J Med Chem 44:10571066.

Dahpour AA, Rahdari P, Sobati Z. 2012. Chemical composition of essential oil, antibacterial activity and brine shrimp lethality of ethanol extracts from Sedum pallidum. J Med Plants Res 6: 31053109.

Demain AL, Sanchez S. 2009. Microbial drug discovery: 80 years of progress. J Antibiot 62: 5-16.

El-Tarabily KA, Hardy GESJ, Sivasithamparam K. 2010. Performance of three endophytic actinomycetes in relation to plant growth promotion and biological control of Pythium aphanidermatum, a pathogen of cucumber under commercial field production conditions in the United Arab Emirates. Eur J Plant Pathol 128:527-539.

García OF, Guerrero C, Roldán A, Soleraa JM, Cerdàc A, Campoy M, Zornoza R, Bárcenasa G, Caravaca F. 2010. Soil microbial biomass and activity under different agricultural management systems in a semiarid Mediterranean agroecosystem. Soil Tillage Res 109: 110115.

Getha K, Vikineswary S. 2002. Antagonistic effects of Streptomyces violaceusniger strain G10 on Fusarium oxysporum f.sp. cubense race 4: indirect evidence for the role of antibiosis in the antagonistic process. J Ind Microbiol Biotechnol 28:303-310.

Gopalakrishnan S, Pande S, Sharma M, Humayun P, Kiran BK, Sandeep D, Vidya MS, Deepthi K, Rupela O. 2011. Evaluation of actinomycetes isolates obtained from herbal vermicompost for the biological control of Fusarium wilt of chickpea. Crop Prot 30: 10701078

Goudjal Y, Toumatia O, Yekkour A, Sabaou N, Mathieuc F, Zitouni A. 2014. Biocontrol of Rhizoctonia solani damping-off and promotion of tomato plant growth by endophytic actinomycetes isolated from native plants of Algerian Sahara. Microbiol Res 169: 59-65.

Haas D, Blumer C, Keel C. 2000. Biocontrol ability of fluorescent pseudomonads genetically dissected: importance of positive feedback regulation. Curr Opin Biotechnol 11:290-297.

Hamdali H, Hfaidi M, Virolle MJ, Ouhdouch Y. 2008. Growth promotion and protection against damping-off of wheat by two rock phosphate solubilizing actinomycetes in a P-deficient soil under greenhouse conditions. Appl Soil Ecol 40: 510-517.

Huddleston A, Cresswell N, Neves M, Beringer S, Baumberg S, Thomas D, Wellington E. 1997. Molecular detection of streptomycinproducing Streptomycetes in Brazilian soils. Appl Environ Microbiol 63: 1288-1297.

Ito M, Sato I, Koitabashi M, Yoshida S, Imai M, Tsushima S. 2012. A novel actinomycete derived from wheat heads degrades 
deoxynivalenol in the grain of wheat and barley affected by Fusarium head blight. Appl Microbiol Biotechnol 96:1059-1070.

Jogaiah S, Kurjogi M, Govind RS, Huntrike S, Bassappa V, Tran PL. 2016. Isolation and evaluation of proteolytic actinomycete isolate as novel inducers of pearl millet downy mildew disease protection. Sci Rep 6: 30789.

Kang S, Chung YJ, Lim JA. 2012. Antifungal and insecticidal activity of essential oil from Asarum sieboldii against wood contaminant fungi and Lasioderma serricorne L. J Conserv Sci 28: 395-401.

Kavitha A, Prabhakar B, Venkateswarlu Y, Vijayalakshmi M. 2010 Purification and biological evaluation of the metabolites produced by Streptomyces sp. TK-VL_333. Res Microbiol 161: 335-345.

Khamna S, Yokota, Lumyong S. 2009. Actinomycetes isolated from medicinal plant rhizosphere soils: diversity and screening of antifungal compounds, IAA, and siderophore production. World J Microbiol Biotechnol 25:649-655.

Khan RA, Al-Farhan K, Almeida A, Alsalme A, Casini A, Ghazzali M, Reedijk J. 2014. Light-stable bis (norharmane) silver (I) compounds: synthesis characterization and antiproliferative effects in cancer cells. J Inorg Biochem 140: 1-5.

Khare A, Singh BK, Upadhyay RS. 2010. Biological control of Pythium aphanidermatum causing damping-off of mustard by mutants of Trichoderma viridae 1433. J Agric Technol 6: 231-243.

Kuo PC, Damu AG, Lee KH, Wu TS. 2004. Cytotoxic and antimalarial constituents from the roots of Eurycoma longifolia. Bioorganic Med Chem 12: 537-544.

Kurniati D. 2017. Isolasi aktinomiset asal rhizosfer kedelai (Glycine max 1.) sebagai agen pemacu pertumbuhan tanaman. [Undergraduate Thesis]. Bogor Agricultural University, Bogor. [Indonesia]

Lim JA, Choi YA, Jung MH, Kang SY, Chung YJ. 2008. Antifungal and insecticidal activity of methanol extract from 11 Korean wood species. J Conserv Sci 23: 95-102.

Mazzola M. 2002. Mechanisms of natural soil suppressiveness to soilborne diseases. Anton Leeuw 81: 557-564.

Mbofung GY, Hong SG, Pryor BM. 2007. Phylogeny of Fusarium oxysporum f. sp. lactucae inferred from mitochondrial small subunit, elongation factor $1-\alpha$, and nuclear ribosomal intergenic spacer sequence data. Phytopathol 97:87-98.

Mohamed AA, Ali SI, Darwesh OM, El-Hallouty SM, Sameeh MY. 2015. Chemical compositions, potential cytotoxic and antimicrobial activities of Nitraria retusa methanolic extract sub-fractions. IJTPR 7: $204-212$
Oloyede GK, Onocha PA, Abimbade SF. 2011. Chemical composition, toxicity, antimicrobial and antioxidant activities of leaf and stem essential oils of Dieffenbachia picta (Araceae). Eur J Sci Res 49: 567580.

Rao VK, Chhikara BS, Shirazi AN, Tiwari R, Parang K, Kumar A. 2011. 3-Substitued indoles: one-pot synthesis and evaluation of anticancer and SRc kinase inhibitory activities. Bioorg Med Chem Lett 21: 3511-3514.

Ravichandiran M, Thiripurasalini S, Ravitchandirane V, Gopalane S, Stella C. 2013. Chemical constituents and anti-tuberculosis activity of ink extracts of cuttlefish, Sepiella inermis. J Coast Life Med 1: 273277.

Semangun H. 2008. Penyakit-penyakit Tanaman Pangan di Indonesia $2^{\text {nd }}$ edition. Yogyakarta.

Sinha K, Hegde R, Kush A. 2014. Exploration on native actinomycetes strains and their potential against fungal plant pathogens. Int J Curr Microbiol App Sci 3: 37-45.

Susilowati A, Wahyudi AT, Lestari Y, Antonius S, Wiyono S. 2011. Potential Pseudomonas isolated from soybean rhizosphere as biocontrol against soilborne phytopathogenic fungi. HAYATI J of Biosci. 18: 51-56.

Vinale F, Sivasitthamparam K, Ghisalberti EL, Marra R, Barbetti MJ, Li H, Woo SL, Lorito M. 2008. A novel role for Trichoderma secondary metabolites in the interactions with plants. Physiol Mol Plant Pathol 72: $80-86$

Yang X, Chen L, Yong X, Shen Q. 2011. Formulations can affect rhizosphere colonization and biocontrol efficiency of Trichoderma harzianum SQR-T037 against Fusarium wilt of cucumbers. Biol Fertil Soils 47:239-248.

Wiyono S. 2003. Optimisation of Biological Control of Damping-off of Sugar Beet (Beta vulgaris L. ssp. vulgaris var. altissima Doell) caused by Phytium ultimum Trow by using Pseudomonas fluorescens B5. [Dissertation]. Georg-August University, Göttingen. [Germany]

Zacky FA, Ting ASY. 2013. Investigating the bioactivity of cells and cellfree extracts of Streptomyces griseus toward Fusarium oxysporum f.sp. cubense race 4. Biol Control. 66: 204-208.

Zhang JX, Xue AG, Tambong JT. 2009. Evaluation of seed and soil treatments with novel Bacillus subtilis strains for control of soybean root rot caused by Fusarium oxysporum and Fusarium graminearum. Plant Dis 93:1317-1323. 